\title{
RURAL TOURISM IN DEVELOPMENT FUNCTION OF RURAL AREAS IN SERBIA
}

\author{
Dejan Dašić ${ }^{1}$ Dragan Živkovićn , Tamara Vujić3 \\ *Corresponding authorE-mail: dasic.dejan@akademijadositej.edu.rs
}

\begin{abstract}
A R T I C LE IN F O
A B S T R A C T

Original Article

This paper analyzes past experiences and examples of

Received: 19 March 2020

Accepted: 29 July 2020 good practice in the development of rural tourism, with particular reference to the potential of Serbia. The aim of this paper is multiple. Given that rural areas in Serbia doi:10.5937/ekoPolj2003719D

UDC 338.48-44(1-22): $330.34(497.11)$ face significant economic and demographic problems, rural tourism may be one of the answers to the question of how to revitalize rural areas. Tourism development in villages of Serbia can make an important contribution to

Keywords:

rural tourism, regionalization, rural areas, economic prosperity, Serbia

JEL: P25, Z32 job creation but also to preserving jobs for the population and increasing their interest in staying in the region and creating new business opportunities. In addition to building a positive image, economic prosperity, by investing more in this area, Serbia could solve the problem of population migration within its territory to larger cities, as well as the departure of young people from the country.
\end{abstract}

(C) 2020 EA. All rights reserved.

\section{Introduction}

No matter how big, powerful and productive a country is, it is competing for its place in the world market every day. The stagnation and continuing slowdown in the global economy is largely due to the "competition" of many destinations to gain the confidence of tourists, consumer investors and producers. There is almost no destination in the world where tourists are not desirable, which is why the definition of xenophobia is changing (Prnjat, 2019).Today, there are numerous, specific ways of branding destinations, and when it comes to tourism, we can see a great expansion of selective forms of tourism. Well-known and already well-developed tourist destinations, due to increasing

1 Dejan Dašić Ph.D., Associate Professor, High school of Academic Studies "Dositej", Vojvode Putnika 7, 11000 Belgrade, Serbia, Phone: +381 1132355 00, E-mail: dasic. dejan@akademijadositej.edu.rs, ORCID ID (https://orcid.org/0000-0002-8245-1117)

2 Dragan Živković Ph.D., Full Professor, High school of Academic Studies "Dositej", Vojvode Putnika 7, 11000 Belgrade, Serbia, Phone: +381 1132355 00, E-mail: zivkovic. dragan@gmail.com, ORCID ID (https://orcid.org/0000-0002-0533-5884)

3 Tamara Vujić, MA, UTD Narcis Divčibare doo, Vojvode Mišića br. 2, 14000 Valjevo, Srbija, Phone: +381 6922720 59; E-mail: tim.hot.vujic@gmail.com, ORCID ID (https:// orcid.org/0000-0002-5445-4222)

http://ea.bg.ac.rs 
competition, are turning to the development of new attractions, such as: military tourism, rural tourism, congress tourism, health tourism, sports, educational, religious tourism, archaeological, urban, recreational, spa, eco and ethno tourism, gastronomy, dark tourism, "abortion and transplant tourism" (Colin, 2011), "slow tourism" etc ...For example, the concept of 'slow tourism' is relatively new and involves people travelling 'slower' and shorter but staying longer in a chosen destination where they use local modes of transport, enjoy local cuisine and visit local, cultural sites (Tomić et al. , 2018).Countries are trying differently to attract more tourists, foreign investors, to develop international partnerships, to stimulate exports, to better position their products and services, but also to position themselves through personally identifiable brands, as effectively, meaningfully and innovatively as possible and in their own wayin the international environment (Cvijanović et al., 2018; Dašić, 2013).

Tourism is an important source of income and a significant factor in economic stability, because it contributes to an increase in foreign exchange inflows and job creation (Dašić, 2018). Over 3.5 million tourists visited Serbia in 2019.Comparing 2018 data, this is an $8 \%$ increase, with more than 1.8 million foreign tourists and as many domestic tourists (Bakić, 2020). What is interesting is that in 2019 the greater number of foreign tourists was recorded for the first time compared to domestic tourists. Also, the number of overnight stays $(10,073,299)$ increased by $8 \%$ compared to 2018 , and particularly important is the data on double-digit growth in the number of overnight stays by foreign tourists.In the Republic of Serbia in December 2019, compared to December 2018 , the number of tourist arrivals increased by $15.0 \%$ and the number of overnight stays increased by $20.4 \%$.(Republic Office of Statistics of Serbia, 2020). As before, the largest number of overnight stays of foreign tourists was realized in Belgrade, Novi Sad, Zlatibor, Vrnjacka Banja and Kopaonik.

Contemporary trends in world tourism are looking for places where nature is fully preserved or living environment minimally altered.Serbia's chances in a picky market may be destinations with no disturbed ambient features of rural areas. Some phenomena of rural tourism include (Baćac, 2011): rural, wine, gastro, hunting and fishing tourism, tourism in national and nature parks, religious tourism, cultural tourism, rural camp, ethno villages, ethno collections, rural manifestations, folklore, adventure tourism, health tourism (spa), etc. With the development of tourism, certainly conditions for better development of rural tourism (rural tourism) will be created, which is underdeveloped in our region, given that a large part of the surface of Serbia is made up of rural areas (Živković et al., 2019).

\section{Literature review}

The number of tourists seeking relaxation in the midst of nature in rural, unspoiled areas is on the rise and the transition from mass tourism to alternative, special interest forms of tourism has been observed, mainly in Western and Northern Europe (Milojević \& Mihajlović, 2019). Niche tourism and buying an "emotional" vacation in lesser known, unique destinations has become a lifestyle among highly educated, well- 
travelled tourists (Maria-Irina, 2017). Growing global environmental concerns provide an opportunity in the form of a new market for "ecotourism". Destinations such as the Maldives, Kenya and Belize, which used this trend and their natural resources to target the ecotourism market, doubled in the 1980s with their tourism business (Ignjatijević et al., 2020). On the one hand, a new generation of environmentally conscious and educated tourists is actively seeking a "pristine" environment as a holiday destination, and on the other, local authorities are trying to achieve sustainability (Moutinho, 2005).

When considering the terms village / countryside, and rustic/rural, it can be observed that there is a difference between the two terms, however, in certain cases, especially when viewed as adjectives, there are almost no differences in description or content. The rural area is often referred to as a countryside area which, in addition to villages, hamlets and other settlements, in the physical-geographical sense, covers the once narrower and wider area, which still creates some confusion in the use of the term village/countryside and rustic/rural.It is also present when rural tourism is to be defined. Rural tourism can be defined as a set of relationships and phenomena arising from the travel and stay of visitors in rural areas.(Njegovan, 2016).

Countryside tourism in Portugal, or rural tourism in this country, is characterized by an area of scattered and fragmented markets, which include Housing Tourism, Rural Tourism, Agritourism, Country Houses and Village Tourism.Housing Tourism consists of houses or residences of recognized architectural value of appropriate size, with care for quality furnishings and décor.Rural Tourism are rustic houses typical of a rural area, located in or near the village.Agritourism provides a special feature of allowing tourists to participate in agricultural activities or complementary forms of animation in which the owners live.Country Houses are private homes and shelters located in rural areas that provide hosting services, whether or not the owners use them as apartments.The fifth type, Village Tourism, was recognized in 2001 and is characterized by a hosting service provided in a set of at least five private homes in the village and integrated in a way, whether or not they are lawfully owned (Correia Loureiro, 2012).

New forms of communication, such as the Internet, social networks and applications that can be downloaded on smart phones or tablets, are the key to improving visibility and promoting the promotion of tourism opportunities in rural areas (Chiara Garau, 2015).According to the Tourism Development Strategy of the Republic of Croatia until 2020, the development of rural tourism should be based on enriching the supply of family rural households, primarily through the establishment of local and regional human-created attractions such as wine cellars, recreational facilities, viewpoints, theme parks and the like.Priority should be given to thematizing supply by grouping rural households (clustering) according to different topics (e.g. family, organic farming, riding programs, cyclotourism, etc.); separate standards are developed for each topic. It is necessary to create a basis for stimulating the development of rural tourism as an important part of the overall tourism offer, with the aim of shaping a competitive and recognizable tourism product.(Bartoluci et al., 2018). 
In Montenegro, tourism is also seen as a means of tackling the social and economic challenges facing rural areas. The specific role of rural tourism for generating jobs and additional farm income has been identified.It is considered possible to raise the standard of living of people in rural areas in Montenegro based on tradition and the new role of agriculture and its connection with other sectors, especially tourism.(Morić, 2013). Rural tourism as part of the overall tourist offer in Macedonia is currently booming. Almost every tourist offer of all the travel agencies contains, among other things, visiting interesting rural tourist areas. Rural tourism is a type of tourism that hasgreat potential. It can, in certain regions, extend the tourist season, which willincrease the number of employees in thissector (Koteski, et al., 2017)In this line, it must be noted that rural tourism currently has strong advantages on theinternational market as it has already played a key role in development of some rural zones that were economically and socially depressed (Simpson, 2008; Chuang, 2010).

\section{Material and method}

The subject of this paper is to analyze and describe the development of rural tourism in recent years and to indicate the limitations and possibilities of its development in the context of the overall rural development of the countries in the region and the European Union with reference to the development and potential of rural tourism in Serbia.The aim is to point out the current state and potential for further strategic directions for the future development of rural tourist destinations in Serbia. For the purposes of this article, secondary information surveys have been conducted, including information available on the Internet and in contemporary literature on rural areas. The method of qualitative analysis of secondary data and descriptive (reproductive) synthesis and the comparative method were applied.

\section{Results and discussion}

\section{Tourism as a driver of national economies}

Tourism can enable higher employment rates, increase in income, decrease of spatial difference, basically economic development.This is also in line with EU cohesion policy objectives. In addition, some forms of tourism, such as ecotourism, contribute to nature conservation and address the sustainable tourism issues that the EU is so focused on. Within the EU, tourism is one of the largest economic sectors with $9 \%$ of employees and $9 \%$ of consumption share. It also represents one of the five export categories in $83 \%$ of all countries in the world and a major source of foreign exchange earnings in almost $38 \%$ of countries. Therefore, it has one of the main roles in the economy of many countries, as a source of employment and a way to fight poverty(Pavlović et al., 2009).

Some authors claim that there is a two-way positive relationship between tourism development and the economy.Tourism has a leading role, playing a growing role in achieving certain macroeconomic goals, such as: rural development, employment, positive impact on the country's balance of payments. It is stated that the share of 
the economy, which is directly and indirectly related to tourism in GDP, is many times higher than the share of tourism branch in GDP, which according to the authors implies a positive effect of tourism on the overall economy of a country.Furthermore, it is argued that public opinion in Serbia has a positive attitude towards tourism as an activity, which automatically places tourism in an important economic branch in Serbia (Petković et.al, 2011).

Further, the geographical position of the neighbouring Croatia makes the country very heterogeneous in climate, nature and cultural heritage.The Croatian tourism sector is primarily known as coastal tourism with its peak and supply in summer (sun and sea). The share of tourism activity in total GDP is increasing every year (Table 1). Thanks to the continental part and significant rural areas (about 93\% of the total area), rural tourism is also becoming an important part of the country's tourism offer. Rural tourism can be seen as part of the solution for rural areas facing depopulation (deagrarization) and low income problems (Grgić et al., 2017).

Table 1. Earnings of countries in the region from tourism

\begin{tabular}{|c|c|c|c|}
\hline Country & 2017 (USD m n) & $2016($ USD m n $)$ & period \\
\hline Albania & 2,049 & 1,820 & $1995-2017$ \\
\hline Austria & 22,408 & 20,971 & $1995-2017$ \\
\hline $\begin{array}{l}\text { Bosnia and } \\
\text { Herzegovina }\end{array}$ & 894 & 773 & $1998-2017$ \\
\hline Bulgaria & 4,678 & 4,164 & $1995-2017$ \\
\hline Macedonia & 331 & 283 & $1995-2017$ \\
\hline Montenegro & 1,109 & 978 & $2007-2017$ \\
\hline Romania & 2,999 & 2,172 & $1995-2017$ \\
\hline Serbia & 1,705 & 1,460 & $2002-2017$ \\
\hline Slovenia & 2,952 & 2,627 & $1995-2017$ \\
\hline Croatia & $11,918(2018)$ & $10,703(2017)$ & $1999-2018$ \\
\hline
\end{tabular}

Source: European Union Tourism Revenue

When talking about good examples in the world, Namibia is certainly one of the countries that has achieved significant economic effects and improved image through rural tourism. This country was relatively unknown and perceived as a land of conflict, violence, insecurity, contagion, hunger and the like.One country, known for its turbulent history, in 2007 surpassed its big neighbour South Africa and became one of the most popular tourist destinations in Africa (Dašić, 2016).Another example is Kenya.The Government of this country, through the Ministry of Tourism and the Kenya Tourism Board, has worked continuously to develop the Western Kenya tourism circle, to become a well-known international and domestic tourist destination.Much of Western Kenya is made up of rural areas of the area, which means that most of the tourism activities and features that the region has to offer are based in rural areas of Western Kenya.Statistics show that about $60 \%$ of the population lives below the poverty line. The ironic part is that the area is endowed with natural resources that have been used mainly for economic activities such as agriculture and trade.Natural wealth has not 
helped to reduce poverty in this area and it is considered that another economic activity, especially tourism, should be developed in order to improve the well-being of the area (Okech et al., 2012).

\section{Rural tourism}

Rural tourism involves and includes a range of activities, services and other amenities organized by local people on family farms in order to attract tourists and create added value for the tourism product (Đekić and Vućić, 2004). The guests are presented with the traditional hospitality and living values of the local population, which is why this type of tourism is a lever of economic development and raising living standards in rural communities, all based on the principles of sustainable development and conservation of natural resources.

For example, Albania is a small country, but has diverse resources. The presence of these resources makes the country have great potential for its further development. Thus, the tourism sector is making an increasing contribution to the country's economy. The statistics clearly show that the number of tourists has increased sharply in the last 15 years. As Albania has a diversity of natural resources ranging from the Alps in the north to the Ionian coast in the south, it has great potential for tourism development while still focusing on rural tourism. However, the current situation of rural tourism is quite weak and in its infancy.Entities currently offering rural tourism face many problems of different nature. The development of Rural Tourism is considered to have made an important contribution to job creation while retaining jobs for the population and increasing their interest in staying in the region and creating new business opportunities. It would also provide more opportunities for young people in rural areas and motivate them to stay and not leave the area to find the best opportunity to live in urban areas or abroad. (Nagy et al., 2017)

An important factor in the development of rural tourism is keeping the tradition in the villages.This refers to the reconstruction of the appearance of the place and the characteristic construction of tourist facilities.In order for the farm to provide additional services to tourists, it must be adequately equipped and organized.The tourist facilities are characteristic and traditional in appearance, while from the inside they can be modernly furnished.This type of tourism is often associated with the nostalgic/native feelings of individual tourists. It is a population that moved to the city, having no more ancestors in the countryside, but still very emotionally attached to the homeland. This type of tourist need very often grows into a residential form of tourism, where the residents of the city centres build country houses in their homeland (Štetić et al., 2014). Further, the villages that are historically and culturally significant are even more likely to succeed in tourism because tourists are quite interested in exploring different local customs and traditions (Blažević et al., 2018).

It is estimated that tourist trends will increase by 3-5\% each year over the next few years.Tourists' expectations will also change with this increase. The visitors, also 
referred to as new tourists, prefer holidays oriented to their interest and buy tourism products that are more based on nature, authenticity and experience.Rural tourism, as one of the new types of tourism, is increasingly popular in the tourism industry. Tourists who want to relax, be active and experience something different together in their holidays are looking for a different and authentic tourism of its kind.On the one hand, rural destinations that are struggling with poverty want to strengthen their local economies.Rural tourism is considered a suitable type for both parties. The support of other stakeholders, such as governments and organizers, should also not be forgotten in this concept. Well-managed communication between actors is vital. This cooperation will respond to the needs and well-being of tourists to the local community, as well as preserving the natural, historical and cultural environment. Rural tourism plays an important role for the sustainability of rural areas.(Gökhan, Reyhan, 2015).

Food or dining experiences are one of the important factors that influence tourists' perception of a destination in some models of destination attractiveness.A group of authors explored the use of food as a form of destination identity from the perspective of destination stakeholders. The results showed that stakeholders believe that food identity is a powerful tool in building the brand and image of the destination.Only in the countryside is the tourist able to follow the ritual process, which begins with the production of food and ends with the preparation of meals and setting them on the table.The opportunity to participate in all stages of this process is characterized by the specificity of this form of tourism "this is yours" (Lin, Pearson, \& Cai, 2011). So consumers are willing to pay any price for products that offer them better health and well-being. Today, consumers are picky, informed and focused on health and healthy lifestyles. The average premium prices of healthy foods compared to traditional foods are shown in Table 2.

Table 2. Average differences in premium prices for healthy foods and beverages compared to traditional foods

\begin{tabular}{|l|l|}
\hline Organic Food \& Beverages & $100 \%$ greater \\
\hline Functional food and beverages & $20-50 \%$ greater \\
\hline „Better for you“ food and beverages & $0-30 \%$ greater \\
\hline Naturally healthy food and drink & $10-40 \%$ greater \\
\hline, Food intolerance“ products & $30-60 \%$ greater \\
\hline
\end{tabular}

Source: Euromonitor International

Rural tourism is both an old and a new phenomenon.Serbia has great potential for the development of rural tourism.Natural beauty combined with culture, traditions, festivals, gastronomic specialties and music, may become a recognizable tourism brand, which could contribute to a significant profit inflow and improve the overall image of the country.However, the current level of competitiveness of Serbia in the field of rural tourism is not particularly high, despite the fact that all natural, cultural and social preconditions for its development already exist (natural resources, significant cultivation) land, large number of agricultural active population, traditional approach to 
agriculture, lack of pollution, as well as the possibility of producing "healthy" foods, good potential for developing complementary activities such as hiking, recreation, hunting, fishing, horseback riding and participating in daily active country folk, traditional local culinary specialties, etc.).Rural tourism in Serbia must become the 'major' industry 'and the generator of a dormant national economy.(Medojevic et al., 2011). The rural environment constantly has to reinvent itself without losing sight of its own identity and it does this in a permanently paradoxical manner. On the one hand, the need to survive based on sustainability, in general and respect for the environment, in particular. And on the other, setting in motion new activities that manage to attract people to settle on a permanent or temporary basis. The proposed activities are especially, although not exclusively, related to leisure and, therefore, rural tourism is a basic instrument for developing the rural environment. Throughout the process, fostering creativity, innovation and information and communication technologies are essential because they help the area to be connected and promote it as a smart rural area (Sanagustin-Fons et al., 2018).

\section{Rural tourism in the function of mitigation of regional unevenness}

Increasing attention is given to tourism development as it can contribute to the social and economic regeneration of rural areas (by supplementary income and employment, and by repopulation and eliminating the social isolation of the area).In this regard, tourism is seen as a way to overcome a number of problems in the development of rural areas around the world.Rural tourism is becoming the engine of economic development and raising the standard of living in rural communities, as it rests on the principles of sustainable development and conservation of natural resources. The main resource for the development of rural tourism is nature, and it is estimated that about three quarters of the world's tourism demand is directed towards natural values and "pristine" spaces.

Due to the importance of rural areas, active support for the development and conservation of these areas is a major goal of national government and international organizations.Rural development policies should primarily have the task of creating a rural development plan at the national level, combined with the support it provides at the local level, which means that support must be decentralized (Fotiadis, 2011). Experience from the European Union confirms that territorial units are a better option for realizing value than it is a country.Croatia and the Czech Republic have a high chance of competing with key players, well committed to EU-28 rural tourist destinations.Bulgaria, Cyprus, Hungary, as well as Romania have interesting rural areas, unique traditions and attractive cultures, potential tourism providers with great opportunities for profit.However, a clear focus and strategic vision for implementing the necessary measures in the sector, and sufficient educational level of the population, adequate infrastructure, absorption capacity, necessary funding, and accurate reporting

of rural tourism data remain important challenges in the areas of rural, agricultural and ecotourism in the new Member States (Maria-Irina, 2017). 
The main strategic goals of Serbian tourism in rural areas should be: competitiveness on the international market, balanced regional development, self-employment and motivation of young people to stay in the countryside, constant protection, implementation and maintenance of high ecological standards for long-term sustainable valorisation of tourism potential of rural areas, development of overall offers for the tourist destination, raising the quality of accommodation for catering and tourist services, encouraging the production of organic food and local products as well as their placements through tourism, education of employees in rural tourism and increasing the share of rural tourism in the total tourist turnover.

Rural poverty is a burning problem in many countries, including Serbia.Some authors state that rural tourism in Serbia is developed in some parts of Vojvodina, central and western Serbia, but is still an under-recognized tourist product at the national level. The development of entrepreneurship in the field of tourism stands out as one of the most effective ways to solve this problem.Focusing on the fair distribution of tangible and intangible assets in the local community area involves adopting the concept of tourism development and entrepreneurship, which is based on Pro-poor Tourism. These include the development of micro-types of businesses, small and family-owned businesses, the development of the tourism business diversifying products and activities traditional to rural households, including a development principle that focuses on the interests of the poorest members of the local community.For this reason, relying on local resources to promote local capacities and increase the level of local community participation in development activities is the key to the success of strategies for the poor (Škrbić et al., 2018).

It takes hard work and effort to help the development of rural tourism in Serbia by education and to encourage all those who intend to run tourist services on their farms. It is also necessary to facilitate job orientation for those who already operate as rural family households in tourism (included in agritourism). It is necessary to further motivate the preservation of: ambient architecture, farmhouses, local specifics, traditions and customs, interesting old arts and crafts, biodiversity, small-scale agricultural production, original products.Further, it is necessary to enable the preservation of the vitality of the village and the attractiveness of the rural way of life, through tourism services, as a motivator for the development of rural areas.All of this needs to be done in the way it was done many years ago in France and other most developed tourist destinations in the world today (Đenadić et al., 2016)

In developed countries such as France, Italy or England, the trend of rural neglect in society has evolved in the opposite direction to migration processes in the Balkan Peninsula.A good example is the marketing concept of advertising in the Provence region of France in the last two decades of the twentieth century. When mass migrations of people from villages to cities and the extinction of smaller settlements in the southern part of France occurred in France in the 1960s, the French decided to pay attention to the reconstruction of desolate areas at the turn of the 1980s and into the 1990s. Young married couples were able to buy affordable homes and properties, and the state provided roads and telecommunications. 
According to the 2002 Poverty Reduction Strategy for Serbia, about 45\% of the total population lives in rural areas, covering almost three quarters of the country's territory. They have been in a state of economic and cultural stagnation for decades, dramatically increasing poverty. Opportunities for employment in non-agricultural activities are very limited. This encourages migratory movements, which are dominated by the most capable and most vital part of the population. In the next step, this specific spiral returns to the problem of even more severe economic backwardness and further deepening of poverty. About 58\% of all the poor live in rural areas. Thus, the proportion of the poor among the rural population is $14.2 \%$. This is more than the poverty of the entire population (10.6\%). This means that every seventh inhabitant is poor. Accordingly, the relative poverty in rural areas is significantly higher, almost double, compared to urban poverty $(7.8 \%)$.

In regional terms, rural poverty is most widespread in parts of Serbia, which are the most vulnerable in terms of overall poverty. Among the poor in rural areas, the majority (30\%) are dependents (elderly without income, housewives, children). The rural poverty rate is highest in South-eastern Serbia and stands at $22.7 \%$, followed by western (14.4\%) and central (13.2\%) Serbia. It is also high in Belgrade $(12.2 \%)$ and Vojvodina $(11.5 \%)$, the lowest in eastern Serbia and the depth of poverty is highest in south-eastern Serbia (5.0\%) (Table 3).

Table 3. Rural poverty by regions in Serbia in 2002.

\begin{tabular}{|l|l|l|l|}
\hline & Poverty rate & The structure of the poor & Depth of poverty \\
\hline Belgrade & $12,2 \%$ & $7,7 \%$ & $2,9 \%$ \\
\hline Vojvodina & $11,5 \%$ & $21,7 \%$ & $2,6 \%$ \\
\hline Western Serbia & $14,4 \%$ & $15,9 \%$ & $3,4 \%$ \\
\hline Central Serbia & $13,2 \%$ & $19,0 \%$ & $3,0 \%$ \\
\hline Eastern Serbia & $10,9 \%$ & $8,7 \%$ & $2,6 \%$ \\
\hline South east Serbia & $22,7 \%$ & $26,8 \%$ & $5,0 \%$ \\
\hline
\end{tabular}

Source: Strategija za smanjenje siromaštva u Srbiji

Rural regions in Serbia differ significantly in social, economic and demographic characteristics. The main problems and trends in which almost all rural regions are involved aremigration, poordiversification of economic activities, large-scale agriculture, high unemployment, lack of employment opportunities, poor and underdeveloped infrastructure, low GDP per capita compared to urban regions and the unpolluted environment facing potential threats.In one study, which analyzed the potential for rural tourism development in Sirić Parish, Kosovo and Metohija, the authors argue that rural tourism would diversify the rural economy, provide additional income to the rural population, reduce unemployment, and reduce disparities in the economic development of rural and urban areas. Tourism is an opportunity for farms that mainly sell primary (unprocessed) agricultural products to sell the food products as tourist products on their properties (Ciutacu, 2009). The conclusion is that the directions that should be taken are: to finance the development of rural tourism and include: infrastructure, staff, tourism 
activities and it is necessary to apply appropriate standardization and categorization of services, especially adequate conditions for accommodation, promotions and sales channels of agro-tourism products in the Republic Serbia, countries in the region and thus support the Serb population in Kosovo and Metohija; migration would be halted by creating the elemental conditions for the general, much higher standard of the rural population of Sirinić Parish (Maksimović et al., 2019).

There is an opportunity to harness the potential of Rural Tourism to support the overall development of tourism in Serbia. However, there are also many gaps and barriers that need to be addressed and removed. Among others, we identify the following major ones: road infrastructure in rural areas, the need for structured rural tourism experiences that include activities, accommodation, and artificial facilities; large seasonal issues affecting rural use and occupancy of tourism, which is extremely low (average 4\% annual occupancy for rural units and 21\% for other accommodation units); lack of international standards and quality of guarantee throughout the tourism sector, especially in the case of accommodation; awareness and development of human resources to understand and seize the opportunities that rural tourism provides in a sustainable way; organization between national, regional and local actors (public and private sector, civil society) in order to manage the development of rural tourism in an efficient and sustainable way (Erdeji et al., 2013). For example, rooms in spas and rooms in rural establishments are treated equally in Serbia.The traditional restaurant should be furnished in a national and traditional style with all the details that make the offer original and authentic. The diversification of accommodation in rural tourism imposes the imperative of recognizing new types of accommodation and incorporating them into statutory mandatory categorization that will guarantee guests adequate quality.In the coming years, Serbia must adapt regulations with the goals of the Master Plan as well as international standards, and classify rural accommodation and criteria for their standardization.Compared to the legislation of the countries of the region (Croatia, Slovenia, Romania), it is necessary to specialize accommodation facilities in rural tourism, to include them in the regulations, of course including all the traditional specificities that Serbia has (Vukosav et al., 2018). It is considered that a strong and efficient transport system, i.e. good transport infrastructure, regardless of the type (road, rail, navigation, air), provides increased interest of tourists but also ensures that the population gets to goods, services, work, entertainment and other people. Sometimes even modest achievements in terms of efficiency and improvement of transport infrastructure can provide significant benefits and brand certain destinations (Mitrović et al., 2004; Dašić et al., 2015).

\section{Conclusions}

Revitalizing life in general in rural areas is one positive effect that results from the development of rural tourism. Rural tourism in Serbia can become a driver and generator of a dormant national economy through the diversification of the rural economy. It can provide additional income to the rural population, reduce unemployment, the 
population migration, improve the image of the state and reduce the disparities in the economic development of rural and urban areas, which are extremely large.Preserving and improving the environment, preserving natural landscapes and historic sites are also positive effects of rural tourism development. The development of rural tourism in Serbia is unfortunately still in its infancy, although there is a long tradition of tourism development, and large spatial differences in the development of this type of tourism and its geographical distribution are evident. In short, regardless of certain developments in this area, considering the achieved level of development of Serbia in the field of rural tourism, we can conclude that it is unsatisfactory."The character of rural tourism development in Serbia must tend to keep the villages alive. The Serbian village must be sustainable. Rural tourism should be seen as a financial support for the survival of the village, because interest in rural life has been reduced or, more precisely, nonexistent. It would also be useful to brand and promote the individuality of each village such as Guča, Mokra Gora."(Medojević et.al.).

Considering all of the above, we can draw a general conclusion.Creating a destination brand, specifically Serbia as a rural tourism destination, takes a holistic approach, while developing a marketing strategy for destination branding. Holistic marketing, as well as holistic brand management, recognizes that "everything is important." Relationship marketing, integrated marketing, internal marketing and social responsibility marketing are components of holistic marketing. The perspective of tourism in the future is a more comprehensive appreciation of the desire of modern tourists to "see and experience". Considering that one of the most important goals of the tourist economy is the expansion of the tourist zone, which provides satisfactory financial results, alternative forms of tourism are more invested in which enables the implementation of tourist activities throughout the year, while respecting the principles of sustainable development.

\section{Conflict of interests}

The authors declare no conflict of interest.

\section{References}

1. Baćac, R. (2011). Rural Tourism Handbook: Step by Step from Idea to Successful Business; Zagreb: Ministry of Tourism of the Republic of Croatia.

2. Bakić, S. (2020). The role of the Central Bank as a participant in the financial derivatives market. Oditor - Časopis za menadžment, finansije i pravo, 6(1), 22-37. doi: https://doi.org/10.5937/Oditor2001021B

3. Bartoluci, M., Starešinić, Z., Franić, D.M., \& Bartoluci, F. (2018). EU fund's assets in the function of rural tourism development in Croatia. Acta Economica Et Turistica, 4(1), 1-120. doi: https://doi.org/10.1515/aet-2018-0005

4. Blažević, M., Peters, K., \& Chen, G. (2018). Developing rural tourism in minority ethnic villages: Zlot and Xiaocang She Ethnic Township. Hotel and Tourist Management, 6(2), 71-78. doi: https://doi.org/10.5937/menhottur1802079B 
5. Chuang, S.T. (2010). Rural tourism: perspectives from social exchange theory. Social Behavior and Personality, 38(10), 1313-1322. doi: https://doi.org/10.2224/ sbp.2010.38.10.1313

6. Ciutacu, C., Chivu, L., \& Iorgulescu, R. (2009). The global financial crisis: management of deficits and debts. Amfiteatru Economic Journal, 11(3), 735-750.

7. Colin, C.M. (2011). Health and medical tourism: Kill or cure for global public health? Tourism Review, 66(1-2), 4-15. doi: https://doi.org/10.1108/16605371111127198

8. Correia Loureiro, S.M. (2012). Tourism in Rural Areas: Foundation, Quality and Experience, doi: https://doi.org/10.5772/37483

9. Cvijanović, D., Simić, N., \& Vukotić, S. (2018). Creating a state brand: brand and branding Serbia. Ekonomika, 64(1), 43-54, doi: https://doi.org/10.5937/ ekonomika1802043C

10. Dašić, D. (2013). Branding of countries and nations. Kultura, 139, 396-415. [inSerbian: Dašić, D. (2013). Brendiranje država i nacija. Kultura]. doi: https://doi. org/10.5937/kultura1339396D

11. Dašić, D. (2018). Management of health and medical tourism: Possible directions of development in the Republic of Serbia. Ekonomski signali: Business magazine, 13(1), 41-56. doi: https://doi.org/10.5937/ekonsig1801041D

12. Dašić, D. (2016). City and/or destination branding. Kultura, 152, 377-393. doi: https://doi.org/10.5937/kultura1652377D

13. Dašić, D., Stamenković, J., Damnjanović, A., \& Đurašković, J. (2015). City tourism for the destination branding. In: Dependability and quality managemant ICDQOM-2015, Čačak, 25-26 Jun, Research Center of Dependability and Quality Managemant, DOM Prijevor, 255- 262.

14. Đenadić, M., Muhi, B., \& Jovanović V.D. (2016). Rural tourism: Serbia’s missed chance, Economics of Agriculture, 63(2), 515-529. doi: https://doi.org/10.5937/ ekoPolj1602515D

15. Erdeji, I., Gagić, S., Jovičić, A., \& Medić, S. (2013). Development of Rural Tourism in Serbia. Journal of Settlements and Spatial Planning, 2, 309-315.

16. Euromonitor International, Retrieved from www.euromonitor.com (January 14, 2020).

17. European Union Tourism Revenue, Retrieved from https://www.ceicdata.com/en/ indicator/european-union/tourism-revenue (February 3, 2020).

18. Fotiadis, A. (2011). The role of tourism in rural development: the role of tourism in rural development through a comparative analysis of a Greek and a Hungarian rural tourism area. Lambert Academic Publishing, Saarbrücken.

19. Garau, C. (2015). Perspectives on Cultural and Sustainable Rural Tourism in a Smart Region: The Case Study of Marmilla in Sardinia (Italy). Sustainability, 7, 6412-6434. doi: https://doi.org/10.3390/su7066412

20. Gökhan, A., \& Reyhan, A.A. (2015). Rural Tourism: A Conceptual Approach. In: Tourism, Environment and Sustainability, Editors Mihaela Dinu, Necdet Hacıŏlu, Cevdet Avc1kurt, Recep Efe, Abdullah Soykan, ST. Kliment Ohridski University Press Sofia, 167-184. 
21. Grgić, I., Hadelan, L., Krznar, S., \& Zrakić, M. (2017) Could rural tourism revitalize rural areas in Croatia? Agroeconomia Croatica, 7(1), 98-108.

22. Ignjatijević, S., Aničić, A., Vapa-Tankosić, J., \& Belokapić-Čavkunović, J. (2020). Determining relationship between economic growth and environmental protection. Oditor - Časopis za menadžment, finansije i pravo, 6(1), 38-48. doi: https://doi. org/10.5937/Oditor2001036I

23. Koteski, C., Majhošev, D., \& Jakovljev, Z. (2017). Possibilities for the development of rural tourism in the Republic Macedonia. Journal of Process Management - New Technologies, 5(2), 18-24. doi: https://doi.org/10.5937/jouproman5-13488

24. Lin, Y.C., Pearson, T.E., \& Cai, L.A. (2011). Food as a form of destination identity: A tourism destination brand perspective. Tourism and Hospitality Research, 11(1), 30-48. doi: https://doi.org/10.1057/thr.2010.22

25. Maksimović, G., Ivanović, T., Milošević, B., \& Sekulić, D. (2019) Factors of the rural tourism development of Sirinicka Zupa in Kosovo and Metohija. Economics of agriculture, 66(4), 1187-1199. doi: https://doi.org/10.5937/ekoPolj1904187M

26. Maria-Irina, A. (2017). Ecotourism, agro-tourism and rural tourism in the European Union,Conference: CACTUS 2017- Contemporary Approaches and Challenges of Tourism Sustainability At: Predeal, Romania; available at : https:/www. researchgate.net/publication/320272966_Ecotourism_agrotourism_and_rural_ tourism_in_the_European_Union

27. Medojevic, J., Milosavljevic, S., \& Punisic, M. (2011). Paradigms of rural tourism in Serbia in the function of village revitalization. Human Geographies- Journal of Studies and Research in Human Geography, 5(2), 93 $\square$ 102, doi: https:/doi. org/10.5719/hgeo.2011.52.93

28. Milojević, I., \& Mihajlović, M. (2019). Implementation of the method of assessing investment projects in the public sector. Oditor - Časopis za menadžment, finansije i pravo, 5(1), 19-31. doi: https://doi.org/10.5937/Oditor1901019M

29. Mitrović, S., Petrović, N., \& Lazić, J.M. (2004). The role of the transportation infrastructure in the SEE development: Case of SM. Industrija, 32(4), 19-36.

30. Moric, I. (2013). The Role and Challenges of Rural Tourism Development in Transition Countries: Montenegro Experiences, Turizam, 17(2), 84-95.

31. Moutinho, L. (2005). Strategic Management in Tourism. Masmedia, Zagreb.

32. Nagy, H., Káposzta, J., \& Meta, B. (2017). The potentials of rural tourism in developing rural areas in Albania. Deturope, 9(3), 188-206.

33. Njegovan, Z. (2016) Economics of tourism and rural tourism, Novi Sad: Faculty of Agriculture, Electra copy \& print studio.

34. Okech, R., Haghiri, M., \& George, P.B. (2012). Rural tourism as a sustainable development alternative: An analysis with special reference to Luanda, Kenya. Cultur, Brasil, 6(3), 36-54.

35. Pavlović, M., Radivojević, N., \& Lazić, J. (2009). Sustainable development of spa tourism in Serbia. Industrija, 37(2), 37-57. 
36. Petković, G., Zečević B., \& Pindžo R. (2011). Tourism as part of national economy. Ekonomika preduzeća, 59(1-2), 89-97. doi: https://doi.org/10.5937/ekopre1102089P

37. Prnjat, A. (2019). Xenophobia and Identitarian Nationalism. In: Xenophobia, Identity and New Forms of Nationalism, Institute of Social Sciences, Belgrade, 240-251.

38. Republic Office of Statistics of Serbia, Retrieved from https://publikacije.stat.gov. rs/G2020/pdf/G20201020.pdf (February 5, 2020).

39. Sanagustin-Fons, V., Lafita-Cortés, T., \& Moseñe A.J. (2018). Social Perception of Rural Tourism Impact: A Case Study, Sustainability, 10(2), 339. doi: https:/doi. org/10.3390/su100

40. Simpson, M.C. (2008). Community benefit, tourism initiative: A conceptual oxymoron. Tourism Management, 29(1), 1-18. doi: https://doi.org/10.1016/j. tourman.2007.06.005

41. Strategija za smanjenje siromaštva u Srbiji, Retrieved from https://www.srbija.gov. rs/extfile/sr/211704/strategija-za-smanjenje-siromastva-u-srbiji_cyr.pdf (January 15, 2020).

42. Škrbić, I., Jegdić, V., \& Milošević, S. (2018). Pro-poor tourism for the purpose of rural environment development. Economics of agriculture, 65(1), 373-389. doi: https://doi.org/10.5937/ekoPolj1801373S

43. Štetić, S., Cvijanović, D., \& Šimičević, D. (2014). Special forms of tourism of the Danube region of Serbia, Institute for Agricultural Economics, Belgrade.[in Serbian:Štetić, S., Cvijanović, D., \& Šimičević, D. (2014). Posebni oblici turizma dunavskog regiona Srbije].

44. Tomić, S., Leković, K., \& Stoiljković, A. (2018). Impact of motives on outcomes of the travel: Slow tourism concept. School of business, 2, 68-82. doi: https://doi. org/10.5937/skolbiz2-19724

45. Vukosav, S., Garača, V., \& Bradić, M. (2018). Analyses of regulations regarding accommodation facilities categorisation in rural tourism in Serbia. Economics of agriculture, 65(2), 769-786. doi: https://doi.org/10.5937/ekoPolj1802769V

46. Živković, A., Pantić, N., \& Rosić, M. (2019). Fiscal sustainability of the macroeconomic system of European Union members. Oditor - Časopis za menadžment, finansije $i$ pravo, 5(2), 32-41. doi: https://doi.org/10.5937/ Oditor1902033Z 